\title{
Radość w nabożeństwie drogi krzyżowej w kontekście przemian językowych i kulturowych
}

Niniejsze opracowanie jest częścią badań nad przemianami stylistycznymi i gatunkowymi drogi krzyżowej w XX wieku. Nabożeństwo to polega na rozważaniu wydarzeń męki Chrystusa w połączeniu z przejściem symbolicznej drogi od miejsca skazania, przez miejsce ukrzyżowania, aż do grobu, w którym Jezus został pochowany. Klasyczne nabożeństwo tego typu składa się z czternastu stacji, przy każdej z nich odmawia się zwykle krótkie formuły modlitewne mające charakter stały oraz wygłasza dłuższe rozważanie, które ma charakter zmienny.

Materiał badawczy stanowią teksty używane podczas odprawiania nabożeństwa, przy czym 100 tekstów pochodzi z pierwszej połowy XX wieku, a 100 tekstów z końca XX wieku i początku naszego stulecia $\cdot$ Teksty tego rodzaju są publikowane bądź w postaci broszurek, bądź w modlitewnikach czy osobnych zbiorach, obecnie także w czasopismach katolickich i internecie ${ }^{1}$. Mogą one służyć jako pomoc dla kapłanów prowadzących nabożeństwo, mogą być także używane przez osoby świeckie do prywatnego odmawiania.

W analizie wykorzystamy elementy koncepcji pola leksykalno-semantycznego (m.in. Tokarski 1984) ${ }^{2}$, która pozwoli zaobserwować z jednej strony specyfikę obrazu uczuć w stylu pasyjnym na tle polszczyzny ogólnej, z drugiej strony przemiany tego stylu w XX wieku.

1 Jest oczywiście pewna różnica między tekstem używanym w momencie odprawiania nabożeństwa (m.in. z powodu roli elementów pozawerbalnych) a tekstem przeznaczonym do tego celu i wydrukowanym, np. w zbiorze dróg krzyżowych, fakt ten nie odgrywa jednak znaczącej roli, jeśli chodzi o badane przeze mnie zagadnienia.

2 Przeprowadzono wiele badań dotyczących metodologii pola semantycznego wywodzącej się m.in. od J. Triera i L. Weisgerbera. Nawet spośród autorów polskich jesteśmy w stanie wymienić tylko niektórych, jak np. D. Buttler, W. Pisarek, R. Tokarski, W. Miodunka, A. Zajda, Z. Cygal-Krupa, E. Siatkowska, A. Mikołajczuk. 
Okazuje się, że znaczącą część leksyki badanych tekstów stanowią nazwy uczuć. Najwięcej wspomnianych nazw należy do pól semantycznych smutku oraz miłości, czego należało oczekiwać. Może się natomiast wydać niezwykły i wart szerszego zbadania fakt, że również leksyka związana z uczuciem radości jest relatywnie częsta i bogata, a zarazem podlega wyraźnym zmianom w ciągu XX wieku.

Ważnym punktem odniesienia naszych badań jest obszerna praca A. Mikołajczuk powstała na podstawie Narodowego Korpusu Języka Polskiego oraz inne prace dotyczące konceptualizacji radości w języku ogólnym (Mikołajczuk 2009; Buttler 1977; Siatkowska 1988; Wierzbicka 1971, 1999).

Jeśli chodzi o radość w ścisłym znaczeniu, czyli grupę semantyczną ${ }^{3}$ radości, w badanym materiale jest ona reprezentowana przez leksemy radość, radosny, radośnie, radować się, cieszyć się, uciecha, pociecha (w niektórych znaczeniach tego słowa), weselić się, wesele, wesoły, zadowolony, zadowolenie, satysfakcja, szczęście, szczęśliwy. Bardziej odległe od centrum pola semantycznego są grupy semantyczne przyjemności, ulgi, dumy, nadziei, z których omówimy w końcowej części opracowania tylko te, które uległy największym zmianom, mającym związek z ewolucją całego pola radości.

$\mathrm{Z}$ braku miejsca nie będziemy analizować dokładnie różnic znaczeniowych pomiędzy poszczególnymi leksemami ${ }^{4}$, wskazując tylko, że wyrazy wesele, weselić się i wesoly odnoszą się z reguły do radości o widocznych objawach, a wyrazy radosny, radośnie, radować się odnoszą się zwykle do radości głębokiej, duchowej. Z kolei leksemy zadowolony, zadowolenie i satysfakcja zawierają komponent intelektualny — ocenę tego, co się z podmiotem dzieje. Bardziej skomplikowana semantycznie jest grupa szczęścia (szczęście, szczęśliwy), która odnosi się nie tylko do uczucia o wielkiej intensywności, lecz także do dobrego losu, pomyślności, a zatem do rozmaitych okoliczności zewnętrznych.

Ze względu na przyczynę, podmiot, charakterystykę czasową, intensywność, wartościowanie i inne kryteria można wyróżnić różne rodzaje radości. Przykładowo A. Mikołajczuk wyróżnia następujące modele poznawcze: radość reaktywna, czynnościowa, zmysłowa, ludyczna, na tle komizmu, radość bez wyraźnej przyczyny, szczęście trwałe i nieprototypowo: radość z cudzego nieszczęścia oraz radość ofiarna (marginalnie wspomina też radość masochistyczną i sadystyczną) (Mikołajczuk 2009, s. 121). Spośród tych modeli w drogach krzyżowych najczęściej możemy odnaleźć radość trwałą, bliską pojęciu szczęścia trwałego — zobaczmy przykłady:

Ja także kiedyś podzielać będę szczęście Twoje w niebiesiech, ale daj Panie, abym dzielić mógł wzgardę i cierpienia Twoje na ziemi (Wiąz. mirry 1900, s. 168).

${ }^{3}$ A. Mikołajczuk wyróżnia grupę semantyczną radości (w sensie ścisłym), która sytuuje się wewnątrz większego mikropola semantycznego (rodziny) radości (Mikołajczuk 2009, s. 113).

4 Różnice te przedstawia szczegółowo cytowana praca (Mikołajczuk 2009). 
Proszę Cię [...], abym teraz współbolejąc z Tobą, mógł kiedyś wspólnie z Tobą się cieszyć (Siedlecki 1959, s. 417).

Pomóż nam cierpieć jak Ty cierpiałaś [...] z tą nadzieją, że nasze cierpienie niezawodnie przemieni się w radość (Trzec. Tys. 20135).

Zwróćmy także uwagę na bardzo charakterystyczne dla gatunku drogi krzyżowej, zwłaszcza dawnej, przeciwstawienia (antytezy) aktualnego cierpienia i przyszłej radości/szczęścia.

Na drugim miejscu, pod względem częstości w drogach krzyżowych, pojawia się radość reaktywna, czyli radość z pomyślnego wydarzenia:

[...] słysząc Cię modlącego się za zabójców swoich, o! jakże się dusza moja raduje (paulin. 1938, s. 40).

Wiosną w lesie przechodzę obok małej kapliczki z obrazkiem Matki Bożej. [...] To moje spotkanie z Nią jest podobne do tego, które miała z Synem na Drodze Krzyżowej. Bo ona zawsze czeka na swoje dziecko na drodze — jaka by nie była (sic!) ta droga. Gdy droga jest dobra - Matka się cieszy, gdy jest zła - cierpi (o krzyżach 2013).

Ciekawy przykład mamy w poniższym fragmencie:

Panie Jezu, spraw, abym [...] żebym jak Maria [Magdalena] potrafił wzruszać się i tęsknić, nie dospać i szukać Ciebie, by i mnie udzieliła się radość Wielkanocnego Poranka i abym na wszystkich ścieżkach żył tą radością (Życiński 2013).

Radość jest tu przygotowana pewnymi dyspozycjami oraz aktywnością podmiotu. Jest to z jednej strony radość reaktywna — spowodowana wydarzeniem zmartwychwstania Jezusa, z drugiej jednak strony radość trwała, radość życia. Jak pisze A. Mikołajczuk, łączenie tych modeli radości jest charakterystyczne dla doświadczenia czasu sakralnego, a zatem dla tekstów religijnych (Mikołajczuk 2009, s. 252).

Radość reaktywna ze zmartwychwstania jest typowa dla współczesnych dróg krzyżowych w odróżnieniu od dawnych. Taki radosny akcent końcowy pojawia się w zdecydowanej większości posoborowych dróg krzyżowych, a tylko w nielicznych tekstach dawnych, co odzwierciedla zmiany w teologii tego nabożeństwa — podkreślanie, że męka i śmierć Chrystusa stanowią dwa nierozłączne aspekty misterium paschalnego (Kopeć 1994, s. 24). Niekiedy jest to związane z dołączeniem osobnej, piętnastej stacji, zob. charakterystyczny tytuł Czternaście przystanków smutnych przed jednym wesołym (Twardowski 2002) 6 .

${ }^{5}$ W przypisach do dróg krzyżowych pochodzących ze źródeł internetowych nie umieszczam numerów stron.

${ }^{6}$ Więcej na ten temat por. (Sieradzka-Mruk 2014). 
Dużo miejsca w drogach krzyżowych zajmuje radość z cudzego nieszczęścia czy nawet radość sadystyczna, które to typy w ogólnym obrazie radości w języku polskim zajmują pozycję marginalną (Mikołajczuk 2009, s. 122-123). Ten rodzaj uczucia przejawiają wykonawcy egzekucji oraz część świadków męki Chrystusa. Może ona także łączyć się z radością na tle komizmu. Nie ma oddzielnych leksemów ${ }^{7}$, które na nią wskazują:

I w tym licznym tłumie krzyż otaczających ludzi, było wielu obojętnych, wielu radujących się na widok cierpień Jezusa [...] (Antoniewicz 1923, s. 62).

Starszyzna żydowska biega, i krzyczy z piekielnem weselem, że już Zwodziciel potępiony (Podgórze 1903, s. 6).

Dlaczego śmiali się, gdy Jezus upadał? Dlaczego zamiast Mu pomóc, kopniakami utrudniali podniesienie się z ziemi? Dlaczego nie było im Go żal?

Dlaczego tak często cieszę się, gdy komuś powinie się noga? Dlaczego czuję wtedy zadowolenie, ba! satysfakcję nawet i dziękuję Bogu, że to właśnie jego, a nie mnie spotkało nieszczęście? (Ważny, młodz. 2009, s. 2003a 88).

Ten ostatni fragment, jak wiele tekstów religijnych, wykorzystuje zasadę analogii (Wojtak 2004, s. 108) — po opisaniu zachowania oprawców w czasie drogi krzyżowej mówiący odnosi tę sytuację do siebie samego.

W drogach krzyżowych należy oczekiwać modelu uczucia, który A. Mikołajczuk określa jako radość ofiarną (Mikołajczuk 2009, s. 123) — radość mimo cierpienia, gdy cierpienie jest znoszone dla wyższych wartości. Sądzę, że to nie jest radość z powodu cierpienia (radość masochistyczna), lecz radość z powodu osiągania pewnych wartości dzięki cierpieniu. W tekstach drogi krzyżowej taką radość przypisuje się Jezusowi:

Jezus bierze krzyż na siebie przygotowany, przyciska go do serca Swego, całuje go z radością i składa na swych ramionach (franciszk. 1916, s. 7).

Oto Jezus bierze radośnie na Swe święte ramiona krzyż, który grzechy moje tak ciężkim uczyniły... (Tomanek 1956, s. 621).

W badanym materiale rzadko jednak pojawia się leksem radość i inne wyrazy $\mathrm{z}$ centrum tego pola semantycznego w odniesieniu do radości ofiarnej, natomiast komponent znaczeniowy tej emocji znajdujemy w wyrazach ochota, ochotny, ochotnie, ochoczo:

Jeśli nam ciężko kiedykolwiek, [...] patrzmy na Jezusa, On bierze krzyż z ochotą (dla kapł., 1937, s. 10).

${ }^{7} \mathrm{~W}$ języku polskim brak leksemów takich, jak niem. Schadenfreude czy ros. zloradstvo (Mikołajczuk 2009, s. 122; Wierzbicka 1999, s. 103-104). 
Panie Jezu Chryste [...] wspomóż mnie łaską Twoją, abym wszelkie przeciwności ochotnie dla miłości Twojej znosił [...] (Łuków 1920, s. 11).

Jakże potrzebna jest na każdy dzień łaska wytrwania, łaska ochotnego podejmowania codziennego krzyża [...] (Wincenc. 2013).

Wyrazy wskazują przede wszystkim na wolę podmiotu, ale mamy tu też do czynienia z elementem emocjonalnym (Mikołajczuk 2009, s. 173-174), co staje się widoczne przy porównaniu $\mathrm{z}$ innymi wyrażeniami tego komponentu pozbawionymi, np.:

[...] dobrowolnie wziął krzyż na swe ramiona (z Maryją 2013).

On bez sprzeciwu bierze swój krzyż [...] (dominik. V 2013).

Na znaczenie związane z radością wskazują też definicje leksemu ochota w niektórych słownikach — wśród synonimów pojawia się m.in. 'radość' (SJPDor), 'entuzjazm' (SJPDun), w WSJP mówi się tylko ogólnie o 'pozytywnym odczuciu', natomiast brak tego znaczenia w SJPSzym. W historii języka polskiego komponent radości w słowie ochota był prawdopodobnie jeszcze ważniejszy (Siatkowska 1988, s. 136) (ślady tego dawnego znaczenia mamy obecnie w leksemie rozochocony).

Leksemy radość oraz ochota i pochodne w tym kontekście, czyli przy stacji Wzięcia krzyża, częściej pojawiają się w dawnych drogach krzyżowych (w 34 tekstach na 100, podczas gdy w materiale współczesnym zaledwie w 6 tekstach). Najwyraźniej w nowszych tekstach kładzie się raczej nacisk na wolę Jezusa, a nie na radość ofiarną. Być może pewną rolę odgrywa chęć uniknięcia skojarzeń z masochizmem.

Inne modele poznawcze radości występują rzadziej w badanym materiale, jak np. radość ludyczna, związana z zabawą, oraz radość zmysłowa, pokrewna przyjemności.

Radość ludyczną ilustruje następujący przykład:

Wieczorem pod krzyżem zrobili ognisko, długo śpiewali i się cieszyli (o krzyżach 2013).

Ten model radości oraz model radości zmysłowej w przedsoborowych drogach krzyżowych często są określane leksemem uciecha albo, wyjątkowo, pociecha:

Wspomnij na to, że masz podwójny powód do płaczu, najprzód nad Jezusem [...], następnie nad sobą samym, że nie umiesz znaleźć uciechy bez obrazy Jego (Wilno 1908, s. 59).

W Tobie zewnątrz i wewnątrz rany tylko, gorycz i boleść, a ja samemi gonię pociechami, dla ciekawego umysłu, dla rozpieszczonego podniebienia, dla rozpustnego ciała! (Podgórze 1903, s. 21). 
Konteksty wskazują często na negatywne wartościowanie tego rodzaju uczuć, co jest dobrze widoczne np. w innej wersji cytowanej wyżej drogi krzyżowej:

[...] masz podwójny powód do płaczu, naprzód nad Jezusem [...], następnie nad sobą samym, że Go obrażasz dla marnej uciechy (paulin. 1938, s. 32).

Leksem uciecha w materiale współczesnych dróg krzyżowych jest bardzo rzadki. W pewnym stopniu został zastąpiony wyrazem przyjemność. Na pole semantyczne radości w sensie ścisłym częściowo nakłada się bowiem pole przyjemności, która różni się przede wszystkim biernością podmiotu doświadczającego. Ponadto przyjemności przypisuje się mniejszą wartość i powierzchowność (Mikołajczuk 2009, s. 115; por. też Wierzbicka 1971, s. 58-63), granice między tymi kategoriami są jednak rozmyte. Oto kilka przykładów z tekstów dróg krzyżowych:

Jakże wiele osób jest obecnie odzieranych z szat szacunku i intymności dlatego, że ktoś kieruje się cynizmem, chciwością, prymitywnym dążeniem do doraźnej przyjemności albo chęcią łatwego zysku (Dziewiecki 2013).

Ci co wiodą tę młodzież na pokuszenie, co dają jej jako rozrywkę dyskoteki, [...] ukazują im życie lekkie i przyjemne, życie w zabawie [...] oni prowadzą ich na bezdroża (o krzyżach 2013).

[...] żałuję z głębi serca, że widząc Ciebie całego we krwi w ranach i gorzkości, ja tyle razy własnej szukałam przyjemności i własnej wygody! (służebnicz. 1948, s. 306).

Nietrudno zauważyć, że w tekstach drogi krzyżowej również leksemy przyjemność/przyjemny niemal zawsze pojawiają się w kontekstach wskazujących na negatywne wartościowanie tego uczucia przez mówiącego. Przyjemność jest skontrastowana $\mathrm{z}$ jednej strony $\mathrm{z}$ cierpieniem Chrystusa, $\mathrm{z}$ drugiej strony $\mathrm{z}$ radością wieczną, jak w przykładzie:

Biedni ludzie, którzy dla chwilowej przyjemności, którą daje grzech, rezygnują z wiecznej radości i wiecznego szczęścia (Trzec. Tys. 2013).

Leksem przyjemność okazuje się typowy dla współczesnych dróg krzyżowych - pojawia się bowiem tylko jeden raz w cytowanym wyżej tekście przedsoborowym, dość późnym (1948).

W dawnych drogach krzyżowych w analogicznych kontekstach — przy stacji Obnażenia z szat - występuje wyraz rozkosz:

Przez zawstydzenie i boleści, których wtedy doznałeś, spraw, abym mężnie wzgardził próżnością i zmysłowymi rozkoszami (Kwiat Eu. 1940, s. 482).

Ale przychodzą czasy, gdy przez schlebianie namiętnościom, zadowolenie chwilowych rozkoszy, odciągają ludzkość od dobra miraże siły (Kiersnowski 1926, s. 53). 
O Jezu niewinny, dla boleści, których doznałeś, gdy Cię z szat obnażono, dopomóż mi do wyzucia się ze zmysłowości i rozkoszy występnych (Toruń 1938, s. 25).

Leksem rozkosz w ogóle nie wystąpił we współczesnym materiale z wyjątkiem ewidentnego cytatu z dawniejszego tekstu. Wyraz ten oznacza najwyższy stopień natężenia uczucia przyjemności (por. SJPDor, SJPDun, WSJP). W niektórych kontekstach z dodatkowym określeniem rozkosz zmysłowa, a zwłaszcza rozkosz występna, grzeszna oznacza grzech przeciw szóstemu przykazaniu. To peryfrastyczne określenie opiera się naturalnie na metonimii — zamiast pewnego zachowania występuje nazwa uczucia mu towarzyszącego. Rozkosz zatem, jak przyjemność, również bywa wartościowana negatywnie, często, lecz nie zawsze, dla wierzącego bowiem źródłem rozkoszy może być także kontakt z sacrum, jak w przykładzie:

O Jezu! o Marjo (sic)! najsłodsze rozkosze serca mego! (Gniezno 1935, s. 31).

Należy zastanowić się nad przyczynami zjawiska polegającego na tym, że w materiale współczesnym leksem rozkosz został niejako wyparty przez leksem przyjemność, który tak bardzo różni się stopniem intensywności uczucia. Być może $\mathrm{w}$ dawnych drogach krzyżowych kontynuujących jeszcze obrazowanie barokowe ${ }^{8}$ większe było upodobanie do kontrastów i antytez. Wobec tego wyraz rozkosz lepiej się nadawał do zestawiania zarówno z cierpieniem Jezusa, jak i ze szczęściem wiecznym. A zatem unikanie tego wyrazu należy uznać za przejaw bardziej powściągliwej pod pewnymi względami stylistyki współczesnej drogi krzyżowej. Należy zauważyć, że współczesne drogi krzyżowe częściej posługują się nazwami uczuć (postaw emocjonalnych) o mniejszej intensywności niż dawne teksty albo nawet nazwami postaw, które komponentu emocjonalnego nie mają, np. zamiast miłości (bliźniego) możemy spotkać życzliwość lub solidarność, zamiast wściekłości w analogicznych kontekstach spotykamy irytację czy zdenerwowanie.

Innym powodem mogą być wspomniane konotacje rozkoszy wskazujące na sferę seksualną. Obecne we współczesnej kulturze zwiększone zainteresowanie seksualnością człowieka wywiera wpływ na gatunek drogi krzyżowej polegający m.in. na unikaniu wzmianek mogących budzić tego rodzaju skojarzenia. Pociąga to za sobą m.in. ograniczenie zakresu użycia wyrazów miłosny, zakochać się, zmniejszenie frekwencji leksemu kochać na rzecz lubić, np. lubić przyjaciela w porównaniu z dawniejszym kochać przyjaciela, unikanie opisu objawów uczuć, takich jak całowanie różnych części ciała zmarłego, a także wspomniane w niniejszym artykule ograniczenie występowania modelu radości ofiarnej ${ }^{9}$.

$8 \mathrm{~W}$ wielu tekstach przedsoborowych można odnaleźć nawiązania do siedemnastowiecznych wzorów — św. Leonarda da Porto Maurizio i św. Alfonsa Liguoriego.

9 Pola semantyczne miłości, a także gniewu w drodze krzyżowej są przedmiotem mojego odrębnego, nieopublikowanego jeszcze studium. 
Jeśli chodzi o połączenia typu występna rozkosz, grzeszna rozkosz, jako peryfrastyczne określenia grzechu przeciwko szóstemu przykazaniu, autorzy współczesnych dróg krzyżowych dążą najwyraźniej do odnowienia słownictwa z tej dziedziny, zatem być może unikanie leksemu rozkosz jest także skutkiem poszukiwania nowych środków wyrazu ${ }^{10}$.

Kolejną grupę semantyczną położoną na peryferiach pola radości stanowi grupa nadziei reprezentowana przez takie leksemy, jak: nadzieja, ufność, ufać, zaufanie. Wyrazy te nie oznaczają wyłącznie emocji, na plan pierwszy wysuwa się w nich raczej komponent intelektualny, co potwierdzają słowniki języka polskiego, w których jako wyrazy definicyjne pojawiają się m.in. 'przeświadczenie' i 'przekonanie' (SJPDor, SJPDun, WSJP). Oprócz tej cechy A. Mikołajczuk podkreśla także ukierunkowanie na przyszłość - emocje te dotyczą tego, co się stanie według przewidywań podmiotu (Mikołajczuk 2009, s. 129). Oto typowe przykłady użycia:

[...] całą swoją nadzieję pokładam w Panu. I mówię z ufnością: Módl się za nami grzesznymi teraz i w godzinie śmierci naszej (o współwinie 2013).

Jezu upadający! bądź mojem (sic!) powstaniem, moją nadzieją i siłą [...] Cała ufność moja w Tobie, Jezu mój! (Jarosz 1926, s. 350).

Przykłady, w których mówi się o tego rodzaju uczuciach, są dość liczne zarówno w dawnych, jak i w nowych drogach krzyżowych. Natomiast we współczesnym nabożeństwie ten obraz uczucia został wzbogacony o nowy aspekt - nadzieję zmartwychwstania, o której wspomina się przy stacji Złożenia do grobu. Chodzi o zmartwychwstanie Jezusa, ale uczucie nadziei płynące $\mathrm{z}$ tego faktu ma wpływać na całe życie uczestników nabożeństwa, zwłaszcza ich postawę wobec śmierci:

Bardzo łatwo w takich sytuacjach stracić nadzieję i sens zycia. Ale jeśli wierzysz, to nie ma sytuacji beznadziejnych. Jeśli wierzysz, to nie ma rozpaczy bez dna, a po każdym Wielkim Piątku przychodzi Niedziela Zmartwychwstania [...] (Pruszcz 2013).

Pogrzeb Twój był tylko przejściem przez grób [...] ku życiu wiecznemu. Nadzieję promieniującą $\mathrm{z}$ tej prawdy pragnę zachować do dnia ostatniego [...] (dominik. VIII 2013).

Każda śmierć [...] jest próbą mojej nadziei, każdy grób jest nakazem pamięci o tamtym grobie, który po niespełna trzech dniach okazał się pusty (Boniecki 2013).

[...] wszyscy ludzie, którzy patrzą w stronę grobu Jezusa Chrystusa, żyją w nadziei zmartwychwstania (Wojtyła 1985, s. 383).

${ }^{10}$ Nazwom grzechów poświęciłam nieopublikowany jeszcze referat wygłoszony na konferencji Język religijny dawniej i dziś (Poznań 2014). 
Na obrzeżach grupy semantycznej nadziei należałoby być może umieścić także wyraz optymizm, który pojawia się w materiale współczesnym:

Nie tracąc humoru i chrześcijańskiego optymizmu, pyta lekarzy po operacji: „coście zrobili ze mną?” (Duda 2005).

Uwielbiam Cię, Panie, w radosnym optymizmie tych, których życie zdaje się być jedną wielką drogą krzyżową (Ważny 2003b, s. 24-25).

Jednym ze składników tej postawy jest spodziewanie się dobra (w przyszłości). Innym jest dostrzeganie dobra w teraźniejszości lub przeszłości, dlatego można tę postawę rozumieć także jako pokrewną radości życia (Mikołajczuk 2009, s. 130). Oczywiście w semantyce tego leksemu zdecydowanie dominuje komponent poznawczy, emocje pozostają zaś na dalszym planie.

Należy zauważyć, że obraz radości w dyskursie pasyjnym różni się od obrazu tego uczucia w polszczyźnie ogólnej. Wybiera się zatem leksemy radosny, radośnie zamiast wesoły, wesolo ze względu na nacisk na radość duchową - trwalszą, o poważniejszych przyczynach, bardziej angażującą podmiot. Pewne modele poznawcze radości występują częściej w badanych tekstach niż w polszczyźnie ogólnej: są to radość trwała i szczęście, które są udziałem Boga, a mogą być udziałem wszystkich wiernych, radość z cudzego nieszczęścia i radość sadystyczna przejawiane przez prześladowców Jezusa, a także radość ofiarna, której podmiotem jest sam Jezus. Charakterystyczne dla tekstów religijnych w ogóle jest łączenie modelu radości reaktywnej z trwałą, np. radość ze zmartwychwstania Jezusa przemienia się niejako w radość przenikającą całe życie chrześcijanina. Niektóre rodzaje uczuć są w badanych tekstach wartościowane negatywnie, np. przyjemność, uciecha i rozkosz.

Przy porównaniu starszych i nowszych tekstów drogi krzyżowej można zauważyć wypieranie pewnych wyrazów przez inne, np. podniosłe radować się jest wypierane przez cieszyć się. Wyraz pociecha ogranicza swoje znaczenie do 'łagodzenia smutku'. Zanikają wyrazy wesele, weselić się, uciecha i rozkosz - pierwsze dwa w związku z tym, że wyraz wesele w języku ogólnym zaczyna oznaczać przede wszystkim przyjęcie ślubne. Natomiast uciecha i rozkosz są zastępowane m.in. słowem przyjemność.

Jak wspomniałam, nieużywanie wyrazu rozkosz wiązać się może z zanikiem upodobania do kontrastów znaczeniowych w nowszych tekstach i z preferowaniem nazw uczuć o mniejszej intensywności. Przyczyną może być też nabranie przez słowo rozkosz konotacji seksualnych, których w pewnych kontekstach autorzy rozważań chcieliby uniknąć. Ma to związek ze zwiększonym zainteresowaniem seksualnością człowieka we współczesnej kulturze.

Charakterystyczne dla nowych tekstów religijnych jest też pojawienie się leksemów satysfakcja i optymizm. Jak powiedzieliśmy, wyrazy te oznaczają nie tylko emocje, lecz także ocenę intelektualną, w przypadku optymizmu chodzi o dość złożoną postawę wobec życia. Wystąpienie tych wyrazów to jeden z przejawów 
tendencji, którą można nazwać intelektualizacją. W tekstach religijnych ostatnich lat można zaobserwować pojawienie się wielu zapożyczonych abstraktów, jak konformizm, pragmatyzm, koniunkturalizm, konsekwencja, dysproporcja, przy czym, co ciekawe, tego typu wyrazy często współistnieją ze słownictwem kolokwialnym.

Pewne różnice między nabożeństwem dawnym i współczesnym możemy zauważyć także jeśli chodzi o częstość pojawiania się poszczególnych modeli radości, np. w tekstach z pierwszej połowy XX wieku o wiele częściej niż obecnie pojawiała się radość ofiarna — radość z cierpienia (osiąganie pewnego dobra dzięki cierpieniu). Natomiast we współczesnych tekstach często spotykamy radość ze zmartwychwstania Jezusa, jako rodzaj radości reaktywnej, i związaną z nią nadzieję powszechnego zmartwychwstania. Taki radosny akcent stanowi obecnie niemal obligatoryjny element kończący nabożeństwo.

Pełny obraz radości w drogach krzyżowych wymagałby również analizy leksemów nazywających objawy radości, a także metafor i metonimii odnoszących się do tego uczucia, co jednak wykracza poza ramy niniejszego opracowania.

\section{Skróty źródeł cytowanych ${ }^{11}$}

Antoniewicz K. (1923), Droga krzyżowa. Siedm (sic!) uwag o siedmiu boleściach N.P. Marji (sic!). Kwiateczki misyjne. Przez krzyż do nieba. Wianek krzyżowy, Wydawnictwo Księży Jezuitów, Kraków.

Boniecki A. (2013), Rozważania drogi krzyżowej, www.drogakrzyzowa.kapucyni.pl (dostęp: 15 marca 2013).

dla kapł. (1937) ${ }^{12}$, Droga Krzyżowa dla kapłanów, Wydawnictwo Apostolstwa Modlitwy, Kraków. dominik.VIII (2013), Droga Krzyżowa VIII, www.dominikanie.com (dostęp: 15 marca 2013).

Duda M. (2005), Droga Krzyżowa z Janem Pawtem II, www.liturgia.wiara.pl (dostęp: 15 marca 2013).

Dziewiecki M. (2013), Rozważania Drogi Krzyżowej. Miłość, która zaskakuje, www.oat.com.pl (dostęp: 15 marca 2013).

franciszk. (1916), Droga Krzyżowa w 14 stacyach ułożona dla pożytku wiernych, nakładem oo. franciszkanów, Kraków.

Gniezno (1935), Droga krzyżowa z wizerunkami stacyj (sic!) oraz Litanja (sic!) o męce Pańskiej, nakładem Drukarni J.B. Lange ${ }^{13}$, Gniezno.

Jarosz S. (1926), Droga krzyżowa, [w:] Pamiątka misyj i rekolekcyj (sic!) (nauki i nabożeństwa), Wydawnictwo Księży Jezuitów, Kraków, s. 347-359.

Kiersnowski K. (1926), Przez Golgotę ku udoskonaleniu, Wydawnictwo Księży Jezuitów, Kraków.

${ }^{11} \mathrm{~W}$ tytułach źródeł stosuję zapis oryginalny, nie zawsze zgodny z normą ortograficzną $\mathrm{i}$ interpunkcyjną.

12 Data imprimatur, brak daty wydania. Bardzo często, szczególnie w starszych modlitewnikach, pomijano datę wydania (czasami także miejsce lub inne dane). Zwykle można jednak ustalić przybliżoną datę na podstawie zamieszczonej w modlitewniku tablicy świąt ruchomych albo daty imprimatur. Zdarza się również, że dokładna nazwa wydawnictwa jest trudna do odtworzenia ze względu na niestaranną redakcję strony tytułowej.

13 Tak na stronie tytułowej. 
Kwiat Eu. (1940) ${ }^{14}$, Droga Krzyżowa, [w:] Kwiat Eucharystyczny, nakład J. Cebulskiego, Kraków, s. 475-486.

Łuków (1920), Droga Krzyżowa okropnej męki Chrystusa Pana dla Okupu Narodu Ludzkiego krwawemi śladami utorowana przez Stolicę Apostolska Duszom prawowiernym do zbawiennej uwagi w XIV. (sic!) Tajemnicach podana, wydawca S. Jabłoński, Łuków.

o krzyżach (2013), Droga Krzyżowa o Krzyżach i Kapliczkach przydrożnych, www.dominikanie. com (dostęp: 15 marca 2013).

o współwinie (2013), Droga Krzyżowa o współwinie, strachu i obojętności, www.dominikanie.com (dostęp: 15 marca 2013).

paulin. (1938), Droga krzyżowa. Gorzkie żale i kilka pieśni wielkopostnych, nakładem oo. Paulinów na Jasnej Górze, Częstochowa.

Podgórze (1903), Droga krzyżowa. Gorzkie żale. Wybór pieśni o męce Pańskiej, nakładem L. Poturalskiego, Podgórze.

Pruszcz (2013), Droga Krzyżowa - rozważania, www.parafiapruszcz.x.pl (dostęp: 15 marca 2013).

Siedlecki J. (1959), Droga krzyżowa, [w]: Śpiewnik kościelny, Wydawnictwo Diecezjalne św. Krzyża, Opole, s. 411-417.

służebnicz. (1948), Droga Krzyżowa, [w:] Modlitewnik Zgromadzenia Sióstr Stużebniczek Bogarodzicy Dziewicy Niepokalanego Poczęcia w Dębicy, Wydawnictwo oo. Karmelitów Bosych, Kraków, s. 290-313.

Tomanek R. (1956), Droga Krzyżowa, [w:] R. Tomanek, Mszalik niedzielny i świąteczny, nakładem Kurii Diecezjalnej w Stalinogrodzie, Opole, s. 621-624.

Torun (1938), Droga Krzyżowa i Gorzkie Żale, Wydawnictwo Instytutu Różańcowego, Toruń.

Trzec. Tys. (2013), Droga Krzyżowa Trzeciego Tysiąclecia, www.dominikanie.com (dostęp: 15 marca 2013).

Twardowski J. (2002), Czternaście przystanków smutnych przed jednym wesołym, [w:] J. Twardowski, Patyki i patyczki, Wydawnictwo Archidiecezji Warszawskiej, Warszawa, s. 82-97.

Ważny T. (2003a), Droga krzyżowa dla młodzieży, [w:] T. Ważny, Pójdę z Tobą droga krzyża, wydawnictwo Fides, Kraków, s. 86-93.

Ważny T. (2003b), Droga krzyżowa z uwielbieniem Jezusa obecnego w świecie, [w:] T. Ważny, Pójdę z Toba droga krzyża, wydawnictwo Fides, Kraków, s. 18-25.

Wiąz. mirry (1900), Droga Krzyżowa, [w:] Wiązanka mirry. Rozmyślania na cześć Przenajświętszej Męki Zbawiciela i ćwiczenia duchowne z rozmaitych ksiag pobożnych zebrane, drukarnia F. Czerwińskiego, Warszawa, s. 163-169.

Wilno (1908), Nabożeństwo na Post Wielki: komplety, Gorzkie żale, droga krzyżowa z dodatkiem pieśni wielkopostnych oraz przygotowanie do św. spowiedzi, nakładem „Przyjaciela Ludu”, Wilno.

Wincenc. (2013), s. Wincencja, Droga krzyżowa 21. Przez mękę do zmatwychwstania, www.drogakrzyzowa.kapucyni.pl (dostęp: 15 marca 2013).

Wojtyła K. (Jan Paweł II) (1985), Droga krzyżowa, [w:] W. Wojdecki, Wierzę w Ciebie, Boże żywy, Wydawnictwo Archidiecezji Warszawskiej, Warszawa, s. 371-383.

z Maryją (2013), Droga krzyżowa z Maryją, www.dominikanie.com (dostęp: 15 marca 2013).

Życiński J. (2013), Droga krzyżowa, www.tygodnik.onet.pl (dostęp: 15 marca 2013).

14 Brak daty wydania, tablica świąt ruchomych od 1940 roku. 


\section{Bibliografia}

Buttler D. (1977), Grupa semantyczna przymiotników polskich o znaczeniu 'pozostający w zwiąku z radościq', „Prace Filologiczne” XXVII, s. 271-286.

Kopeć J.J. (1994), Wstęp, [w:] Droga krzyżowa. Duchowość nabożeństwa i antologia współczesnych tekstów polskich, red. J.J. Kopeć, Niepokalanów, s. 7-35.

Mikołajczuk A. (2009), Obraz radości we wspótczesnej polszczyźnie, Warszawa.

Siatkowska E. (1988), Pole semantyczne 'szczęścia'i pojęć pokrewnych w historii języka polskiego, „Prace Filologiczne” XXXIV, s. 127-141.

Sieradzka-Mruk A. (2014), Innowacje gatunkowe wspótczesnej drogi krzyżowej, [w:] Bogactwo wspótczesnej polszczyzny, red. P. Żmigrodzki, S. Przęczek-Kisielak, Kraków, s. 309-316.

SJPDor (2014), Stownik języka polskiego, red. W. Doroszewski, doroszewski.pwn.pl (dostęp: 1 maja 2014).

SJPDun (1999), Stownik wspótczesnego języka polskiego, red. B. Dunaj, Warszawa.

SJPSzym (1988), Stownik języka polskiego, red. M. Szymczak, Warszawa.

Tokarski R. (1984), Struktura pola znaczeniowego (studium językoznawcze), Lublin.

Wierzbicka A. (1971), Kocha, lubi, szanuje. Medytacje semantyczne, Warszawa.

Wierzbicka A. (1999), Język - umyst - kultura. Wybór prac pod red. J. Bartmińskiego, Warszawa.

Wojtak M. (2004), Styl religijny w perspektywie genologicznej, [w:] Język religijny dawniej i dziś, red. S. Mikołajczak, T. Węcławski, Poznań, s. 104-113.

WSJP (2014), Wielki słownik języka polskiego, red. P. Żmigrodzki, www.wsjp.pl (dostęp: 1 maja 2014).

\section{Radość (joy) in devotion of Stations of the Cross in the context of changes of language and culture}

\section{Summary}

The article presents the specificity of the image of joy in the discourse of Catholic devotion of the so-called Way of the Cross (Stations of the Cross) and changes of conceptualization of this emotion that occurred in the twentieth century. The study uses elements of methodology of the lexical-semantic field. The analysis is based on about 100 Polish texts used in the Way of the Cross published during the first half of the twentieth century and 100 contemporary texts of devotional practice (after the II Vatican Council).

The study is an attempt to explain why some words are replaced by others, for example what are the reasons for a frequent use of the word przyjemność (pleasure) instead of the word rozkosz (delight). It highlights the emergence of new lexemes in the discourse, such as optymizm (optimism), satysfakcja (satisfaction). It also shows changes in the frequency of occurrence of different subcategories of joy, for example disappearance of the model of sacrificial joy and appearance of the joy of the Resurrection.

Keywords: language of religion, Stations of the Cross, names of emotions, semantic field 